\title{
Opłata za korzystanie z programu komputerowego jako usługi**
}

T echnologia chmur obliczeniowych (cloud computing), w tym zwłaszcza model oprogramowania jako usługi (Software as a Service, SaaS), zyskuje coraz bardziej na znaczeniu gospodarczym zarówno w Polsce, jak i zagranicą ${ }^{1}$. Ten sposób eksploatacji programu komputerowego, jak sygnalizowałem wcześniej, istotnie różni się od przeważającego obecnie udzielania licencji na korzystanie $\mathrm{z}$ omawianego utworu, utrwalonego na nośniku danych ${ }^{2}$. Do cech charakterystycznych Software as a Service zalicza się przy tym nierzadko powiązanie wysokości wynagrodzenia uiszczanego przez użytkownika z rozmiarem rzeczywistego korzystania z programu komputerowego ${ }^{3}$. Co więcej, takie ukształtowa-

* DR Krzysztof ŻoK - Katedra Prawa Cywilnego, Handlowego i Ubezpieczeniowego, Uniwersytet im. Adama Mickiewicza w Poznaniu; e-mail: krzysztof.zok@amu.edu.pl

** Niniejszy artykuł stanowi efekt realizacji projektu badawczego $\mathrm{nr}$ 2015/19/D/HS5/00006, pt. Charakter prawny umów dotyczacych przetwarzania w chmurze obliczeniowej (cloud computing), wykonywanego w ramach grantu udzielonego przez Narodowe Centrum Nauki w konkursie Sonata 10.

${ }^{1}$ Zob. K. Żok, Kwalifikacja umowy o korzystanie z programu komputerowego jako ustugi (Software as a Service, SaaS) - uwagi na tle prawa polskiego i wybranych zagranicznych systemów prawnych, „Zeszyty Naukowe Uniwersytetu Jagiellońskiego. Prace z Prawa Własności Intelektualnej” 2015, z. 129, s. 19-20 wraz z powołaną tam literaturą.

${ }^{2}$ Zob. K. Żok, Kwalifikacja umowy..., s. 18-32; K. Żok, Prawna i ekonomiczna analiza umowy o korzystanie z programu komputerowego jako usługi (Software as a Service, SaaS), „Zeszyty Naukowe Uniwersytetu Jagiellońskiego. Prace z Prawa Własności Intelektualnej” 2017, nr 4, s. 63-78.

${ }^{3}$ M. Małyszko, SAAS jako metoda świadczenia e-usług, Warszawa 2008, s. 13 (publikacja dostępna na stronie Polskiej Agencji Rozwoju Przedsiębiorczości - www.parp.gov.pl, 30.06.2017); J. Marly, Praxishandbuch. Softwarerecht, München 2009, s. 450-451; A. Mateos, J. Rosenberg, Chmura obliczeniowa. Rozwiazania dla biznesu, Gliwice 2011, s. 9, 28, 39, 42; T. Mather, S. Kumaraswamy, S. Latif, Cloud Security and Privacy. An Entreprise Perspective on Risks and Compliance, Sebastopol 2009 , s. 7-8, 18. Tak też ogólnie w odniesieniu do chmury obliczeniowej P. Mell, Th. Grance, The NIST Definition of Cloud Computing, s. 2, http://dx.doi.org/10.6028/NIST.SP.800-145, 30.06.2017; E. Molenda-Kropielnicka, Cloud Computing - zagadnienia prawne, „Zeszyty Naukowe Uniwersytetu Jagiellońskiego. Prace z Prawa Własności intelektualnej” 2013, z. 119, s. 112, 130-131, 148. E. Stau- 
nie odpłatności uważa się za czynnik zwiększający ekonomiczną atrakcyjność umowy o oprogramowanie jako usługę w porównaniu do dominującej aktualnie umowy licencji ${ }^{4}$. Celem niniejszego opracowania jest przedstawienie występujących w praktyce modeli wynagradzania za korzystanie z programu komputerowego w chmurze obliczeniowej, a także udzielenie odpowiedzi na pytanie, czy sposób, w jaki opłata ta jest ukształtowana, faktycznie istotnie odbiega od rozwiązań przyjmowanych $w$ umowie licencji. Na tej podstawie możliwe jest w szczególności zbadanie, czy przepisy ustawy o prawie autorskim i prawach pokrewnych mogą stanowić punkt odniesienia dla wspomnianego świadczenia spełnianego przez użytkownika Software as a Service ${ }^{5}$.

\section{Funkcja ochronna regulacji wynagrodzenia w prawie autorskim}

Normy prawne wysłowione w rozdziale 5 ustawy o prawie autorskim i prawach pokrewnych nierzadko opierają się implicite na założeniu, w świetle którego twórca zazwyczaj występuje jako słabsza strona zobowiązania ${ }^{6}$. Uregulowanie to pełni zatem funkcję podobną do przepisów o ochronie konsumenta. Słusznie jednak wskazuje się na różne uzasadnienie obu tych regulacji. Ochrona twórcy wynika bowiem ze strukturalnej dysproporcji siły ekonomicznej kontrahentów $\mathrm{w}$ ramach pierwotnych stosunków z zakresu prawa autorskiego ${ }^{7}$. Wzmocnienie sytuacji prawnej konsumenta stanowi natomiast konsekwencję asymetrii informacji, która mogłaby być z kolei wykorzystywana przez przedsiębiorców.

degger, Rechtsfragen beim Erwerb von IT-Systemen, w: Informatikrecht, red. D. Jahnel, A. Schramm, E. Staudegger, Wien 2003, s. 87 J. Stawicki, Cloud Computing: idea, historia, możliwości i praktyka, w: Techniczne i ekonomiczne aspekty cloud computing, red. O. Lesicka, Warszawa 2010, s. 9; J. Szyjewska-Bagińska, w: Ustawa o prawie autorskim i prawach pokrewnych. Komentarz, Warszawa 2016, s. 440. Zob. też komunikat z 27.9.2012 r., Wykorzystanie potencjału chmury obliczeniowej w Europie, $\operatorname{COM}(2012) 529$ final, s. 4.

${ }^{4}$ A. Mateos, J. Rosenberg, Chmura obliczeniowa..., s. 31-32; T. Mather, S. Kumaraswamy, S. Latif, Cloud Security..., s. 17-18; J. Soma, M. Nichols, M.M. Gates, A. Gutierrez, Chasing the Clouds without Getting Drenched: a Call for Fair Practices in Cloud Computing Services, "Journal of Technology Law \& Policy" 2001, nr 16, s. 202.

${ }^{5}$ Ustawa z dnia 4 lutego 1994 r. o prawie autorskim i prawach pokrewnych (t. jedn. Dz.U. z 2017 r., poz. 880 z późn. zm.), dalej: „u.p.a.p.p.”.

${ }^{6}$ Zob. M. Kępiński, w: System Prawa Prywatnego. Prawo autorskie, t. 13, red. J. Barta, Warszawa 2017, s. 698-699, 703; T. Targosz, w: T. Targosz, K. Włodarska-Dziurzyńska, Umowy przenoszące autorskie prawa majątkowe, Warszawa 2010, s. 22-23; K. Włodarska-Dziurzyńska, w: T. Targosz, K. Włodarska-Dziurzyńska, Umowy przenoszace autorskie prawa majątkowe, Warszawa 2010, s. 225-226; podobnie: J. Szyjewska-Bagińska, Ustawa o..., s. 436, 438. Szerzej E. Traple, Ustawowe konstrukcje w zakresie majątkowych praw autorskich i obrotu nimi w dobie kryzysu prawa autorskiego, „Rozprawy habilitacyjne” 1990, nr 179, s. 107-122; D. Sokołowska, Prawo twórcy do wynagrodzenia w prawie autorskim, Poznań 2013, s. 253-254, która omawia funkcje wynagrodzenia.

7 T. Targosz, Umowy przenoszace..., s. 22-23. 
Powyższa różnica przekłada się na odmienny sposób łagodzenia i usuwania faktycznej nierównowagi kontraktowej stron. Ustawodawca wyposaża wprawdzie twórcę w uprawnienia pozwalające domagać się przekazania określonych danych przez kontrahenta. Uwaga ta dotyczy w szczególności roszczenia informacyjnego, o którym mowa w art. 47 u.p.a.p.p. Niemniej ochrona twórcy - w odróżnieniu od ochrony konsumenta - nie polega w zasadzie na udzielaniu mu dodatkowych informacji. Bezzasadne byłoby bowiem powiadamianie osoby, która stworzyła utwór, o właściwościach tego dobra niematerialnego. Dane odnoszące się do przedmiotu świadczenia stanowią tymczasem nierzadko podstawowe informacje, które powinien uzyskać konsument. Taki obowiązek przewidziano w szczególności expressis verbis $\mathrm{w}$ art. 8 ust. 1 pkt 1 i art. 12 ust. 1 pkt 1 ustawy o prawach konsumenta ${ }^{8}$.

Uprawnienia informacyjne twórcy należy raczej postrzegać jako element szerszej regulacji ochronnej. Normy prawne zawarte w rozdziale 5 ustawy o prawie autorskim i prawach pokrewnych nakierowane są bowiem przede wszystkim na przeciwdziałanie „nadmiernemu” wyzbywaniu się praw przez osobę, która stworzyła utwór". Uzyskanie określonych danych od kontrahenta ma w tym świetle znaczenie instrumentalne, a nie samodzielne. Wymieniony środek prawny służy mianowicie realizacji zasadniczego celu, jakim jest zapewnienie twórcy odpowiedniego wynagrodzenia. Nierzadko osoba, która stworzyła utwór, gotowa jest, zwłaszcza na początku swojej działalności twórczej, udzielić licencji albo przenieść przysługujące jej prawa wyłączne w zamian za nieproporcjonalnie niską opłatę albo wręcz nieodpłatnie ${ }^{10}$.

Aktualność dotychczasowych uwag budzi wątpliwości w przypadku oprogramowania. Wspomniane dobra niematerialne są bowiem wytwarzane przez zespoły programistów, zatrudnionych przez dużych, często zagranicznych przedsiębiorców. Wniosek ten dotyczy w szczególności oprogramowania standardowego, nakierowanego na zaspokajanie typowych potrzeb przeciętnego użytkownika. Konsekwentnie zatem podmioty wytwarzające programy komputerowe przeważnie nie mają statusu twórcy sensu stricto. Niemniej, zgodnie $\mathrm{z}$ art. 74 ust. 3 u.p.a.p.p., przedsiębiorcy ci nabywają w sposób pierwotny i ex lege autorskie prawa majątkowe do programów komputerowych stworzonych przez ich pracowników w ramach wykonywania obowiązków ze stosunku pracy, o ile umowa nie stanowi inaczej. Rozwiązanie to zdaje się zatem upodabniać sytuację prawną producenta oprogramowania do sytuacji prawnej twórcy sensu stricto.

${ }^{8}$ Ustawa z dnia 30 maja 2014 r. o prawach konsumenta (t. jedn. Dz.U. z 2017 r., poz. 683 z późn. zm.).

9 M. Kępiński, System Prawa..., s. 698, 703.

${ }_{10}$ Tamże, s. 703; K. Włodarska-Dziurzyńska, Umowy przenoszące..., s. 225. Podobnie Sąd Najwyższy w wyroku z dnia 4 lutego 1965 r., II CR 536/64, „Orzecznictwo Sądu Najwyższego. Izba Cywilna i Izba Pracy i Ubezpieczeń Społecznych” 1965, nr 12, poz. 215 odniósł się krytycznie do praktyki ustalania najniższych stawek wynagrodzenia dla debiutujących autorów. 
Tym bardziej, jeśli uwzględni się wynikające $z$ art. 77 u.p.a.p.p. ograniczenie autorskich praw osobistych do programu komputerowego oraz przesunięcie części tych uprawnień do sfery autorskich praw majątkowych ${ }^{11}$.

Ryzyko dysproporcji świadczeń stron rozkłada się zatem odmiennie w przypadku programów komputerowych i pozostałych utworów. Nierzadko bowiem to użytkownik znajduje się w trudniejszej sytuacji ekonomicznej i prawnej niż dostawca oprogramowania. W literaturze zwraca się w szczególności uwagę na niedopasowanie przepisów o umowie licencji do specyfiki obrotu omawianym dobrem niematerialnym ${ }^{12}$. Dostawcy programów komputerowych mogą bowiem instrumentalnie wykorzystywać normy prawne w rozdziale 5 ustawy o prawie autorskim i prawach pokrewnych w celu zwiększenia swojej przewagi gospodarczej. Takie działanie wykraczałoby poza funkcję ochronną wymienionych przepisów. Powyższa konkluzja nie powinna być jednak w mojej ocenie nadmiernie uogólniana. Często bowiem sytuacja ekonomiczna podmiotów, które tworzą programy komputerowe w celu zaspokojenia indywidualnych potrzeb użytkownika, nie odbiega w Polsce istotnie od sytuacji ekonomicznej twórców innych utworów ${ }^{13}$. Nie można więc wykluczyć w tym przypadku wystąpienia wskazanej wcześniej strukturalnej nierównowagi kontrahentów.

Korzystanie z programu komputerowego jako usługi stanowi źródło dalszych wątpliwości. Eksploatacja oprogramowania w chmurze obliczeniowej wiąże się bowiem potencjalnie z niedostatkiem informacji o istotnych cechach świadczenia dostawcy, takich jak wyłączenie odpowiedzialności tego podmiotu za szkody powstałe w wyniku nieprawidłowego działania systemu, możliwość jednostronnej zmiany wysokości opłaty lub ograniczenie prawa do wypowiedzenia umowy ${ }^{14}$. Wymienione postanowienia kontraktowe mogą zatem prowadzić do swoistego „uwięzienia” użytkownika w wykreowanym zobowiązaniu

${ }^{11}$ J. Barta, R. Markiewicz, w: Prawo autorskie i prawa pokrewne, red. J. Barta. R. Markiewicz, Warszawa 2011, s. 462; J. Barta, R. Markiewicz, Prawo autorskie, Warszawa 2016, s. 299; K. Gienas, w: Ustawa o prawie autorskim i prawach pokrewnych. Komentarz, red. E. Ferenc-Szydełko, Warszawa 2016, s. 643; A. Szewc, G. Jyż, Ochrona programów komputerowych, informacji i baz danych, Bytom 2001, s. 51; podobnie J. Barta, R. Markiewicz, A. Matlak, Prawo autorskie w społeczeństwie informacyjnym, w: System Prawa Prywatnego. Prawo autorskie, t. 13, red. J. Barta, Warszawa 2017, s. 1273; D. Czajka, Ochrona praw twórców i producentów. Prawo autorskie i prawa pokrewne, Warszawa 2010, s. 141, 144. Z kolei K. Święcka, J.S. Święcki, Prawo autorskie u prawa pokrewne. Komentarz. Wybór międzynarodowych aktów prawnych, Warszawa 2004, s. 126-127 uznają, że zmiana programu komputerowego jest możliwa w ramach użytku prywatnego. Spostrzeżenie to wydaje się jednak nieprzekonujące, biorąc pod uwagę art. 77 u.p.a.p.p.

${ }_{12}$ J. Barta, R. Markiewicz, Z perspektywy legalnego dysponenta, „Zeszyty Naukowe Uniwersytetu Jagiellońskiego. Prace z Prawa Własności Intelektualnej” 2012, z. 118, s. 19-20; podobnie zdaje się D. Czajka, Ochrona praw..., s. 152.

${ }_{13}$ Zob. K. Żok, Środki ochrony zamawiającego program komputerowy. Odpowiedzialność twórcy za usterki utworu, Warszawa 2015, s. 97-101.

${ }^{14}$ E. Molenda-Kropielnicka, Cloud Computing..., s. 144-148. 
(vendor lock-in). Spostrzeżenie to wskazuje z kolei na występowanie asymetrii informacji i aktualność ochrony użytkownika chmury obliczeniowej na podobieństwo ochrony konsumenta. Technologia cloud computing w porównaniu do dotychczasowego udostępniania programu komputerowego na nośniku danych zwiększa ponadto możliwość wyłączenia osób nieuprawnionych od korzystania $\mathrm{z}$ tego utworu ${ }^{15}$. W konsekwencji dostawca oprogramowania może teoretycznie osiągać zyski z prowadzonej działalności bez odwoływania się do konstrukcji z zakresu prawa autorskiego, w tym także rozwiązań o charakterze ochronnym. Powyższe uwagi wydają się istotne ze względu na fakt, że umowa o oprogramowanie jako usługę jest nierzadko przedstawiana jako alternatywa wobec przeważającego obecnie udzielania licencji na programy komputerowe udostępniane na nośnikach danych.

\section{Systemy ustalania wysokości wynagrodzenia za korzystanie z utworu}

Modelowo wyróżnia się trzy główne systemy (sposoby) ustalania odpłatności za korzystanie z utworu. Świadczenie to można bowiem ukształtować jako wynagrodzenie (1) ryczałtowe, (2) procentowe albo (3) mieszane ${ }^{16}$. W pierwszym przypadku wysokość opłaty jest ustalona kwotowo i nie zależy od okoliczności powstałych po zawarciu umowy. W drugim przypadku wielkość świadczenia należnego podmiotowi uprawnionemu zostaje powiązana $\mathrm{z}$ określonym miernikiem korzyści osiąganych dzięki utworowi, np. z liczbą sprzedanych egzemplarzy lub dochodami uzyskanymi z utworu, co na płaszczyźnie normatywnej odzwierciedla w szczególności art. 47 i art. 48 u.p.a.p.p. Wynagrodzenie mieszane stanowi natomiast połączenie dwóch wcześniejszych rozwiązań. Ustawodawca nie wiąże przy tym określonego systemu remuneracji z danym rodzajem umowy prawnoautorskiej. Słusznie jednak formułuje się praktyczną wskazówkę, w świetle której wynagrodzenie ryczałtowe na ogół okaże się bardziej adekwatne dla umowy przenoszącej prawa wyłączne, a wynagrodzenie procentowe - dla umowy licencji ${ }^{17}$.

${ }^{15}$ Zob. K. Żok, Prawna i..., s. 67-69, 72-75.

${ }_{16}$ Zob. J. Barta, R. Markiewicz, Prawo autorskie..., 2016, s. 352, 361; M. Kępiński, System Prawa..., s. 769-770; K. Włodarska-Dziurzyńska, Umowy przenoszace..., s. 227-229; podobnie J. Barta, R. Markiewicz, Prawo autorskie..., 2011, s. 315; A. Szewc, Wynagrodzenia twórców i wykonawców w prawie autorskim i wynalazczym, Sopot 1999, s. 310-311; J. Szyjewska-Bagińska, Ustawa o..., s. 439-440; T. Targosz, w: Prawo autorskie i prawa pokrewne, red. D. Flisak, Warszawa 2015, s. 666; M. Załucki, w: Ustawa o prawie autorskim i prawach pokrewnych. Komentarz, red. P. Ślęzak, Warszawa 2017, s. 412. Szerzej D. Sokołowska, Prawo twórcy..., s. 255-256.

17 T. Targosz, Prawo autorskie..., s. 667. 
Podobnie także w modelu Software as a Service można wyróżnić kilka typowych sposobów ustalania wysokości wynagrodzenia dostawcy oprogramowania w chmurze obliczeniowej. Nierzadko szczególnie akcentuje się w tej mierze powiązanie wielkości wspomnianego świadczenia z rozmiarem rzeczywistej eksploatacji omawianego utworu przez użytkownika ${ }^{18}$. Formuła ta, określana angielskim wyrażeniem pay-per-use, charge-per-use lub pay-as-you-go, polega na uzależnieniu wysokości rozważanej opłaty od takich parametrów jak czas lub częstotliwość używania programu komputerowego, ilość danych przesyłanych przez sieć czy stopień zużycia mocy obliczeniowej serwerów. Konsekwentnie zatem często opisany sposób ustalania wysokości wynagrodzenia dostawcy chmury obliczeniowej uważa się za jedną z cech charakterystycznych umowy o oprogramowanie jako usługę.

Nie negując tego spostrzeżenia, należy w mojej ocenie zaznaczyć, że rozważana odpłatność przybiera w praktyce również inne postacie. Wynagrodzenie dostawcy chmury obliczeniowej często ukształtowane jest bowiem jako opłata zależna od liczby użytkowników (pay-per-user) albo jako stała opłata abonamentowa (subscription fee) ${ }^{19}$. Zwrócenie uwagi przede wszystkim na model pay-per-use wynika zapewne z faktu, że ta postać odpłatności wydaje się najistotniej odbiegać od znanych w prawie autorskim systemów remuneracji.

\section{Opłata oparta na modelu pay-per-use}

Odpłatność za korzystanie z programu komputerowego udostępnianego na nośniku danych przybiera przeważnie postać wynagrodzenia ryczałtowego, określanego jako opłata licencyjna ${ }^{20}$. Świadczenie to ma charakter jednorazowy albo okresowy. Odpłatność za korzystanie z oprogramowania jako usługi może być ukształtowana podobnie. Teoretycznie wynagrodzenie w modelu Software as a Service może przybrać postać świadczenia jednorazowego. Takie rozwiązanie byłoby jednak nieracjonalne z ekonomicznego punktu widzenia. Dostawca oprogramowania $\mathrm{w}$ chmurze obliczeniowej ponosi bowiem powtarzające się koszty związane z utrzymaniem infrastruktury informatycznej, które w pewnym

${ }_{18}$ Zob. przypis nr 3.

19 Th. Hoeren, IT-Vertragsrecht. Praxislehrbuch, Köln 2012, s. 299-300, 303; M. Małyszko, SAAS jako..., s. 13; J. Marly, Praxishandbuch..., s. 450-451; M. Michalski, Ocena efektywności ekonomicznej cloud computing, w: Techniczne i ekonomiczne aspekty cloud computing, red. O. Lesicka, Warszawa 2010, s. 27; A. Monarcha-Matlak, Karta praw klientów chmury, w: Internet. Cloud Computing. Przetwarzanie w chmurach, red. G. Szpor, Warszawa 2013, s. 177; E. Staudegger, Rechtsfragen beim..., s. 87.

${ }^{20}$ J. Barta, R. Markiewicz, Programy komputerowe i prawo, Wrocław 1991, s. 61; M. Byrska, Ochrona programu komputerowego w nowym prawie autorskim, Warszawa 1994. s. 70; G. Fröhlich-Bleuler, Softwareverträge. System-, Software-Lizenz- und Software-Pflegevertrag, Bern 2004, s. 240; D. Rowland, U. Kohl, A. Charlesworth, Information Technology Law, London 2012, s. 428. 
momencie przewyższyłyby jednorazową zapłatę spełnioną przez użytkownika. Opłata abonamentowa za korzystanie z programu komputerowego jako usługi wydaje się natomiast zbliżona pod względem ekonomicznym do opłaty licencyjnej ukształtowanej jako świadczenie okresowe. Spostrzeżenie to nie przekreśla jednak różnic między wymienionymi wynagrodzeniami.

Wniosek ten wydaje się szczególnie aktualny w przypadku oparcia wynagrodzenia za korzystanie z programu komputerowego jako usługi na modelu pay-per-use. Opłata licencyjna jest bowiem wnoszona w zasadzie za samą możliwość korzystania z utworu ${ }^{21}$. Konsekwentnie zatem niepodjęcie albo zaniechanie korzystania $\mathrm{z}$ tego dobra niematerialnego nie uchyla spoczywającego na licencjobiorcy obowiązku zapłaty. Jak wskazano w wyroku Sądu Apelacyjnego w Poznaniu z dnia 16 stycznia 2014 r., zaprzestanie prowadzenia działalności gospodarczej, na potrzeby której pozyskano utwór, nie skutkuje wygaśnięciem obowiązku uiszczania opłat licencyjnych ${ }^{22}$. Tymczasem opłata w przypadku Software as a Service, jak wskazywano wcześniej, zależy od rozmiaru rzeczywistej eksploatacji omawianego dobra niematerialnego. Nieużywanie programu komputerowego powinno zatem spowodować obniżenie wynagrodzenia dostawcy tego utworu w chmurze obliczeniowej. Użytkownik technologii cloud computing decyduje ponadto o funkcjach oprogramowania, z których chce skorzystać $\mathrm{w}$ danej chwili, co przekłada się na wysokość spełnianego przez niego świadczenia ${ }^{23}$.

Trzeba jednak zauważyć, że ustawodawca nie wskazuje enumeratywnie sposobów obliczania wynagrodzenia $\mathrm{z}$ tytułu korzystania $\mathrm{z}$ utworu ${ }^{24}$. Określone $\mathrm{w}$ art. $47 \mathrm{i}$ art. 48 u.p.a.p.p. metody kalkulacji tego świadczenia mają bowiem charakter przykładowy i dotyczą jedynie przypadków typowych. Tym samym de lege lata możliwe jest powiązanie także opłaty licencyjnej z rozmiarem rzeczywistego używania dobra niematerialnego, chronionego przez prawo autorskie. Taką konkluzję zdaje się ogólnie potwierdzać wyrok Sądu Apelacyjnego w Warszawie z dnia 14 czerwca $2013 \mathrm{r} .{ }^{25} \mathrm{~W}$ powołanym orzeczeniu przyjęto mianowicie, że umowa licencji może przewidywać obowiązek uiszczenia opłaty licencyjnej tylko w razie faktycznego używania utworu. W literaturze zagranicznej zwraca

${ }^{21}$ P. Wasilewski, „Odsprzedaż” niematerialnych kopii programów komputerowych, KPP 2014, z. 2, s. 418-419; M. Załucki, Ustawa o..., s. 412. Częściowo odmiennie E. Traple, Umowy o eksploatacje utworów w prawie polskim, Warszawa 2010, s. 62-63, 213-214 w zakresie rozpowszechnienia utworu. Odmiennie zdaje się także J. Szyjewska-Bagińska, Ustawa o..., s. 577-578.

${ }^{22}$ Wyrok Sądu Apelacyjnego w Poznaniu z dnia 16 stycznia 2014 r., I ACa 1166/13, Legalis nr 775911.

${ }^{23}$ M. Małyszko, SAAS jako..., s. 12.

${ }^{24}$ J. Barta, R. Markiewicz, Prawo autorskie..., 2011, s. 315; T. Targosz, Prawo autorskie..., s. 666. Zob. wyrok Sądu Najwyższego z dnia 25 marca 2004 r., II CK 90/03, „Orzecznictwo Sądu Najwyższego. Izba Cywilna” 2005, nr 4, poz. 66.

${ }^{25}$ Wyrok Sądu Apelacyjnego w Warszawie z dnia 14 czerwca 2013 r., VI ACa 1624/12, Legalis nr 749032 . 
się z kolei uwagę na występowanie w praktyce licencji metrycznych (licence per metrics), w przypadku których odpłatność za udostępnione oprogramowanie zależy od rozmiaru korzystania $\mathrm{z}$ tego utworu ${ }^{26}$. Opisana konstrukcja nie wydaje się wprawdzie rozpowszechniona w obrocie programami komputerowymi. Niemniej spostrzeżenie to osłabia ostrość wcześniejszego przeciwstawienia opłaty licencyjnej i opłaty za korzystanie z programu komputerowego jako usługi.

Uwaga ta nie zmienia natomiast faktu, że przeważnie odpłatność z tytułu eksploatacji oprogramowania udostępnionego na egzemplarzach charakteryzuje się brakiem elastyczności. Powyższa cecha wpływa z kolei na ekonomiczną atrakcyjność modelu Software as a Service. Użytkownik nie ponosi w takim przypadku dużych kosztów początkowych w celu pozyskania omawianego dobra niematerialnego, jego instalacji i aktualizacji oraz zakupu odpowiedniego sprzętu ${ }^{27}$. Ponadto z opracowania sporządzonego na zlecenie Komisji Europejskiej wynika, że 1 euro wydane na oprogramowanie w chmurze obliczeniowej odpowiada 2,30 euro wydanym wcześniej dla osiągnięcia podobnego rezultatu ${ }^{28}$. W doktrynie francuskiej wskazuje się także, że technologia cloud computing pozwala zaoszczędzić $20-40 \%$ wydatków ${ }^{29}$. Zbliżone wnioski przedstawia się również w literaturze polskiej, w której podnosi się, że całkowity koszt korzystania $\mathrm{z}$ Software as a Service $\mathrm{w}$ pierwszym roku jest od pięciu do dziesięciu razy niższy niż w przypadku eksploatacji programu komputerowego na nośniku danych na podstawie umowy licencji ${ }^{30}$.

Nie negując tych spostrzeżeń, trzeba jednak w mojej ocenie zaznaczyć, że dotyczą one jedynie krótkiego okresu. Korzyści związane z modelem Software as a Service maleją bowiem wraz $\mathrm{z}$ wydłużaniem się czasu eksploatacji oprogramowania ${ }^{31}$. W długim okresie może nawet okazać się, że program komputerowy jako usługa jest rozwiązaniem droższym niż pozyskanie rozważanego utworu po zapłaceniu jednorazowej opłaty licencyjnej. Doniosłość tej uwagi osłabia jednak szybkie starzenie się oprogramowania i związany z tym spadek użyteczności tego dobra niematerialnego.

${ }^{26}$ D. Rowland, U. Kohl, A. Charlesworth, Information Technology..., s. 428; W. Straub, Informatikrecht. Einführung in Softwareschutz, Projektverträge und Haftung, Bern 2003, s. 186.

${ }_{27}$ Zob. Th. Hoeren, IT-Vertragsrecht..., s. 299; M. Małyszko, SAAS jako..., s. 8-9, 11; A. Mateos, J. Tosenberg, Chmura obliczeniowa..., s. 31-32; T. Mather, S. Kumaraswamy, S. Latif, Cloud Security..., s. 18; M. Michalski, Ocena efektywności..., s. 23, 27, 32; J. Stawicki, Cloud Computing..., s. 11; K. Żok, Kwalifikacja umowy..., s. 20 wraz z powołaną tam literaturą.

${ }_{28}^{28}$ D. Bradshaw, G. Cattaneo, R. Lifonti, J. Simcox, Uptake of Cloud in Europe. Follow-up of IDC Study on Quantive estimates of demand for Cloud Computing in Europe and the likely barriers to take-up, Luxembourg 2014, 11, 34 (DOI: 10.2759/791317, 30.06.2017 r.).

${ }^{29}$ H. Bitan, Droit et expertise des contrats informatique, Rueil-Malmaison 2010, s. 309.

${ }^{30}$ M. Małyszko, SAAS jako..., s. 10.

${ }^{31}$ J. Marly, Praxishandbuch..., s. 450; M. Michalski, Ocena efektywności..., s 32. 


\section{Technologia cloud computing a sposób obliczania opłaty}

Nieupowszechnienie się licencji metrycznych wynika, jak sądzę, $\mathrm{z}$ istotnych trudności w zapewnieniu, by podmioty nieuprawnione nie używały programu komputerowego utrwalonego na nośniku danych. Chmura obliczeniowa, w odróżnieniu od egzemplarza, pozwala natomiast osiągnąć wspomnianą wyłączalność eksploatacji już pierwotnie, tj. na poziomie technicznym, a nie wtórnie, przez konstrukcję praw wyłącznych i umowy o korzystanie z utworu.

Stwierdzenie to wskazuje zarazem na znaczącą różnicę między oprogramowaniem w chmurze obliczeniowej i oprogramowaniem na nośniku danych. $\mathrm{W}$ przypadku wciąż przeważającego sposobu korzystania $\mathrm{z}$ wymienionego utworu użytkownik otrzymuje egzemplarz, na którym utrwalony jest program komputerowy ${ }^{32}$. Ma on więc bezpośredni dostęp do omawianego dobra niematerialnego, wobec czego może zarówno eksploatować ten przedmiot prawa autorskiego zgodnie $\mathrm{z}$ zawartą umowę lub w granicach zezwolenia $\mathrm{z}$ art. 75 ust. 1 u.p.a.p.p., jak i podejmować działania niedozwolone, np. kopiować lub modyfikować oprogramowanie albo przeprowadzać dekompilację poza zakresem art. 75 ust. 2 pkt 3 i art. 75 ust. 3 u.p.a.p.p. Jeżeli zatem opłata licencyjna byłaby powiązana $\mathrm{z}$ rozmiarem faktycznego korzystania z programu komputerowego na nośniku danych, utwór ten mógłby być powielony zanim licencjodawca uzyskałby środki wystarczające na pokrycie poniesionych kosztów ${ }^{33}$. Ponadto brak kontroli nad rozważanym rezultatem intelektualnym utrudniałby skalkulowanie należnego wynagrodzenia.

W przypadku Software as a Service użytkownik nie ma natomiast przeważnie bezpośredniego dostępu do głównego oprogramowania w chmurze obliczeniowej $^{34}$. Utwór ten eksploatowany jest bowiem zwykle za pośrednictwem innych programów komputerowych, takich jak przeglądarki stron internetowych lub aplikacje typu klient ${ }^{35}$. Te ostatnie nie muszą być udostępniane przez dostawcę chmury obliczeniowej. Dowolna przeglądarka internetowa pozwala, przykładowo, uruchomić edytor tekstu lub arkusz kalkulacyjny w technologii cloud computing. Uwaga ta nie zmienia natomiast faktu, że użytkownik nie ma możliwości skopiowania głównego programu komputerowego, dokonania w nim zmian czy

${ }^{32}$ Tamże; R. Sikorski, Umowy dotyczace oprogramowania, w: Umowy w obrocie gospodarczym, red. A. Koch, J. Napierała, Warszawa 2015, s. 394-395; E. Traple, Umowy o..., s. 277.

33 K. Żok, Prawna i..., s. 64-67, 69-72, 74-76.

34 F. Koch, Computer-Vertragsrecht, Freiburg-München-Berlin 2009, s. 365-366, 412-414; J. Marly, Praxishandbuch..., s. 453-454; M. Małyszko, SAAS jako..., s. 9; P. Mell, T. Grance, The NIST..., s. 2; A. Monarcha-Matlak, Karta praw..., s. 176; H. Redeker, IT-Recht, München 2012, s. 361; E. Staudegger, Rechtsfragen beim..., s. 87; podobnie Th. Hoeren, IT-Vertragsrecht..., s. 299-300; E. Traple, Umowy o..., s. 294; W. Straub, Informatikrecht. Einführung..., s. 220.

35 F. Koch, Computer-Vertragsrecht..., s. 412; W. Straub, Informatikrecht. Einführung..., s. 221. 
tym bardziej poznania kodu źródłowego. Opisane ryzyko, charakterystyczne dla aplikacji na nośniku danych, nie zachodzi zatem lub jest istotnie ograniczone w przypadku programu komputerowego jako usługi.

Powyższe rozważania wskazują ponadto, że dostawca oprogramowania mógłby domagać się dwóch wynagrodzeń za dostarczenie tej samej funkcjonalności, jeżeli udostępnił on nie tylko główny program komputerowy w chmurze obliczeniowej, lecz także aplikację pomocniczą (tzw. klienta, client), niezbędną do korzystania $z$ tego programu. Niewykluczone mianowicie, że wspomniany podmiot pobierałby w takim przypadku opłatę za eksploatację głównego oprogramowania (np. w modelu pay-per-use) oraz opłatę licencyjną za aplikację pomocniczą. Takie rozwiązanie, jak się wydaje, rzadko występuje w praktyce $z$ uwagi na koszty, jakie ponosiłby wtedy użytkownik. Warto jednak zauważyć, że podobne zagadnienie wyłoniło się na tle orzeczenia w sprawie Half-Life 2, rozpatrywanej przez niemiecki Sąd Najwyższy (Bundesgerichtshof $)^{36}$. W powyższym wyroku rozdzielono bowiem sferę eksploatacji nośnika, na którym utrwalono wspomnianą grę komputerową, i sferę internetowego „konta” (account) użytkownika, na którym zapisana była postać gracza. Co więcej, budowa rozważanego oprogramowania wykluczała skorzystanie z gry Half-Life 2 przez osobę nieposiadającą konta, nawet jeżeli dysponowała ona legalnie nabytym egzemplarzem tego utworu.

Konsekwentnie zatem przepisy prawa autorskiego mogłyby znaleźć zastosowanie $\mathrm{w}$ odniesieniu do wynagrodzenia za korzystanie $\mathrm{z}$ aplikacji pomocniczej. Należy w szczególności podkreślić, że pominięcie kwestii odpłatności $\mathrm{w}$ umowie o korzystanie $\mathrm{z}$ tzw. klienta może powodować $\mathrm{w}$ świetle art. 43 ust. 1 u.p.a.p.p. obowiązek zapłaty wynagrodzenia, jakkolwiek trudnego do obliczenia. Jak wskazuje bowiem wyrok w sprawie Half-Life 2, nie można także z góry wykluczyć przypadków instrumentalnego posłużenia się normami prawa autorskiego przez powiązanie wysokości opłaty za korzystanie z oprogramowania pomocniczego $\mathrm{z}$ rozmiarem eksploatacji głównego programu komputerowego w chmurze obliczeniowej.

\section{Opłata oparta na modelu pay-per-user}

Analizując sposoby ustalania odpłatności za korzystanie z oprogramowania jako usługi, warto w mojej ocenie zwrócić uwagę także na model pay-per-user, zakładający powiązanie wysokości tego świadczenia z liczbą użytkowników eksploatujących omawiany utwór. Trzeba przy tym od razu zaznaczyć, że powyższa metoda określania wynagrodzenia nie stanowi zazwyczaj przedmiotu

${ }^{36}$ Wyrok BGH z 11.2.2010 r., I ZR 178/08, http://juris.bundesgerichtshof.de, 2.2.2018 r. 
pogłębionej analizy w doktrynie. Tymczasem zdaje się ona nawiązywać do wyróżnianych w literaturze zagranicznej opłat przewidzianych w tzw. licencjach „płynnych” lub „konkurujących” (floating, concurrent license) ${ }^{37}$. Wysokość świadczenia licencjobiorcy zależy bowiem w tym przypadku od liczby użytkowników korzystających jednocześnie z oprogramowania. Spostrzeżenie to ponownie zatem rodzi wątpliwości co do zasadności akcentowania sposobu ustalania wynagrodzenia dostawcy programu komputerowego w chmurze obliczeniowej jako cechy wyróżniającej model Software as a Service na tle innych kontraktów dotyczących omawianego utworu.

Rozważany sposób określania wysokości opłaty za korzystanie z oprogramowania jako usługi zdaje się także nawiązywać do wynagrodzenia autorskiego zależnego od liczby sprzedanych egzemplarzy. W obu przypadkach odpłatność powiązana jest bowiem $\mathrm{z}$,jednostkami" utworu udostępnionym innym podmiotom. Trzeba jednak zauważyć, że osoba korzystająca z programu komputerowego w chmurze obliczeniowej może go eksploatować na dowolnej liczbie urządzeń. Tymczasem oprogramowanie udostępniane na nośniku danych jest zwykle instalowane na oznaczonej liczbie komputerów. Uwaga ta wskazuje zarazem na różnicę między modelem Software as a Service i budzącymi kontrowersje $\mathrm{w}$ prawie autorskim klauzulami CPU lub OEM (ang. license per CPU, niem. CPU Klausel, OEM-Vereinbarung), charakterystycznymi dla umów licencyjnych $\mathrm{w}$ zakresie oprogramowania standardowego ${ }^{38}$. Te ostatnie postanowienia umowne ograniczają mianowicie możliwość korzystania $\mathrm{z}$ rozważanego utworu w ten sposób, że jego eksploatacja może odbywać się tylko na określonym urządzeniu.

Na tym tle powstaje jednak wątpliwość, czy art. 48 u.p.a.p.p. znajduje zastosowanie, choćby per analogiam, do modelu pay-per-user. Sądzę, że w tej mierze należy udzielić odpowiedzi negatywnej. Powołany przepis dotyczy bowiem jedynie sprzedawania egzemplarzy utworu przez dystrybutora, z którym podmiot uprawniony zawarł umowę. Model Software as a Service nie jest tymczasem nakierowany na osiąganie korzyści w wyniku zbywania przez użytkownika nośników danych, na których utrwalono oprogramowanie. Umowa o oprogramowanie jako usługę nie skutkuje również przeniesieniem praw do egzemplarza lub do samego utworu. Nie odpowiada ona więc elementom przedmiotowo istotnym kontraktu stypizowanego w art. 535 k.c.

Konkluzji tej nie zmienia odwołanie się do pojęcia przeniesienia własności kopii programu komputerowego w rozumieniu przedstawionym w wyroku Trybunału Sprawiedliwości Unii Europejskiej z dnia 3 lipca 2012 r. w sprawie

${ }^{37}$ D. Rowland, U. Kohl, A. Charlesworth, Information Technology..., s. 428.

${ }_{38}$ Zob. G. Fröhlich-Bleuler, Softwareverträge. System-..., s. 65-266; F. Koch, Software- und..., s. 532; J. Marly, Praxishandbuch. Softwarerecht..., s. 442-445; D. Rowland, U. Kohl, A. Charlesworth, Information Technology..., s. 428; E. Staudegger, Rechtsfragen beim..., s. 82; W. Straub, Informatikrecht. Einführung..., s. 22; E. Traple, Umowy o..., s. 283-284. 
UsedSoft GmbH przeciwko Oracle International Corp. ${ }^{39} \mathrm{~W}$ wymienionym orzeczeniu wskazano bowiem, że sprzedaż, o jakiej mowa w art. 4 ust. 2 dyrektywy w sprawie ochrony prawnej programów komputerowych, zachodzi w razie bezterminowego udzielenia zezwolenia na korzystanie $\mathrm{z}$ omawianego utworu w zamian za zapłatę jednorazowego wynagrodzenia odpowiadającego wartości gospodarczej kopii tego dobra niematerialnego ${ }^{40}$. Odpłatność w modelu Software as a Service przybiera natomiast zazwyczaj postać świadczenia okresowego. Umowa o oprogramowanie jako usługę nie skutkuje także nabyciem praw eksploatacyjnych bezterminowo. Tym samym nie następuje również przeniesienie własności kopii rozważanego utworu.

W literaturze proponuje się przy tym, by zakres zastosowania art. 48 u.p.a.p.p. obejmował wszystkie przypadki, gdy korzyści osiągane przez podmiot eksploatujący utwór zależą od jednostkowych umów dotyczących wspomnianego dobra niematerialnego, a wynagrodzenie autorskie odnosi się do opłat związanych z tymi umowami ${ }^{41}$. Niemniej nawet $\mathrm{w}$ takim ujęciu wynagrodzenie dostawcy chmury obliczeniowej nie jest powiązane z ewentualnymi umowami zawartymi przez użytkownika $z$ osobami trzecimi. Trudno także przyjąć, by użytkownik dokonywał odsprzedaży oprogramowania udostępnionego w chmurze obliczeniowej.

\section{Podsumowanie}

Model oprogramowania jako usługi nierzadko przedstawia się jako alternatywę wobec wciąż przeważającego modelu licencjonowania programów komputerowych udostępnianych na nośnikach danych. Do cech odróżniających wymienione sposoby eksploatacji utworu zalicza się w szczególności metodę ustalania wynagrodzenia należnego autorowi. W świetle dotychczasowych rozważań należy zauważyć, że odpłatność w przypadku Software as a Service odbiega istotnie od opłat licencyjnych występujących najczęściej w praktyce. Te ostatnie mogłyby jednak przybrać postać zbliżoną do opłat za korzystanie z programu komputerowego jako usługi. Wynagrodzenie przewidziane w licencjach metrycznych podobnie jak wynagrodzenie dostawcy omawianego utworu w chmurze obliczeniowej zależy bowiem od rozmiaru rzeczywistej eksploatacji dobra niematerialnego. Odpłatność w licencjach płynnych wydaje się z kolei zbliżona do

${ }^{39}$ Wyrok TSUE z 3.7.2012 r., C-128/11, w sprawie UsedSoft GmbH przeciwko Oracle International Corp., źródło: curia.europa.eu.

40 Wyrok TSUE z 3.7.2012 r., C-128/11, w sprawie UsedSoft GmbH przeciwko Oracle International Corp., pkt 45-47, źródło: curia.europa.eu.

${ }^{41}$ T. Targosz, Prawo autorskie..., s. 701-702. K. Włodarska-Dziurzyńska, Umowy przenoszace..., s. $256-257$. 
odpłatności opartej na modelu pay-per-user. Odmienność w zakresie ustalania wysokości opłaty za korzystanie z programu komputerowego jako usługi stanowi więc raczej konsekwencję zastosowania technologii chmur obliczeniowych. Ta ostatnia pozwala bowiem skutecznie wyłączyć osoby nieuprawnione od eksploatacji omawianego dobra niematerialnego już na poziomie technicznym. Cel ten w przypadku oprogramowania udostępnianego na nośnikach danych osiągany jest natomiast niejako wtórnie, tj. przez konstrukcję praw wyłącznych.

\section{Bibliografia:}

J. Barta, R. Markiewicz, Prawo autorskie, Warszawa 2016.

J. Barta, R. Markiewicz, w: Prawo autorskie i prawa pokrewne, red. J. Barta. R. Markiewicz, Warszawa 2011.

J. Barta, R. Markiewicz, A. Matlak, Prawo autorskie w społeczeństwie informacyjnym, w: System Prawa Prywatnego. Prawo autorskie, t. 13, red. J. Barta, Warszawa 2017.

J. Barta, R. Markiewicz, Programy komputerowe i prawo, Wrocław 1991.

J. Barta, R. Markiewicz, Z perspektywy legalnego dysponenta , Zeszyty Naukowe Uniwersytetu Jagiellońskiego. Prace z Prawa Własności Intelektualnej" 2012, z. 118.

H. Bitan, Droit et expertise des contrats informatique, Rueil-Malmaison 2010.

D. Bradshaw, G. Cattaneo, R. Lifonti, J. Simcox, Uptake of Cloud in Europe. Follow-up of IDC Study on Quantive estimates of demand for Cloud Computing in Europe and the likely barriers to takeup, Luxembourg 2014.

M. Byrska, Ochrona programu komputerowego w nowym prawie autorskim, Warszawa 1994.

D. Czajka, Ochrona praw twórców i producentów. Prawo autorskie i prawa pokrewne, Warszawa 2010.

G. Fröhlich-Bleuler, Softwareverträge. System-, Software-Lizenz- und Software-Pflegevertrag, Bern 2004.

K. Gienas, w: Ustawa o prawie autorskim i prawach pokrewnych. Komentarz, red. E. Ferenc-Szydełko, Warszawa 2016.

Th. Hoeren, IT-Vertragsrecht. Praxislehrbuch, Köln 2012.

M. Kępiński, w: System Prawa Prywatnego. Prawo autorskie, t. 13, red. J. Barta, Warszawa 2017.

F. Koch, Computer-Vertragsrecht, Freiburg-München-Berlin 2009.

M. Małyszko, SAAS jako metoda świadczenia e-usług, Warszawa 2008.

J. Marly, Praxishandbuch. Softwarerecht, München 2009.

A. Mateos, J. Rosenberg, Chmura obliczeniowa. Rozwiq̨zania dla biznesu, Gliwice 2011.

T. Mather, S. Kumaraswamy, S. Latif, Cloud Security and Privacy. An Entreprise Perspective on Risks and Compliance, Sebastopol 2009.

P. Mell, T. Grance, The NIST Definition of Cloud Computing, Gaithersburg 2011.

M. Michalski, Ocena efektywności ekonomicznej cloud computing, w: Techniczne i ekonomiczne aspekty cloud computing, red. O. Lesicka, Warszawa 2010.

E. Molenda-Kropielnicka, Cloud Computing - zagadnienia prawne, „Zeszyty Naukowe Uniwersytetu Jagiellońskiego. Prace z Prawa Własności intelektualnej" 2013, z. 119.

A. Monarcha-Matlak, Karta praw klientów chmury, w: Internet. Cloud Computing. Przetwarzanie w chmurach, red. G. Szpor, Warszawa 2013.

H. Redeker, IT-Recht, München 2012.

D. Rowland, U. Kohl, A. Charlesworth, Information Technology Law, London 2012.

R. Sikorski, Umowy dotyczace oprogramowania, w: Umowy w obrocie gospodarczym, red. A. Koch, J. Napierała, Warszawa 2015.

D. Sokołowska, Prawo twórcy do wynagrodzenia w prawie autorskim, Poznań 2013. 
J. Soma, M. Nichols, M.M. Gates, A. Gutierrez, Chasing the Clouds without Getting Drenched: a Call for Fair Practices in Cloud Computing Services, "Journal of Technology Law \& Policy" 2001, nr 16.

E. Staudegger, Rechtsfragen beim Erwerb von IT-Systemen, w: Informatikrecht, red. D. Jahnel, A. Schramm, E. Staudegger, Wien 2003.

J. Stawicki, Cloud Computing: idea, historia, możliwości i praktyka, w: Techniczne i ekonomiczne aspekty cloud computing, red. O. Lesicka, Warszawa 2010.

W. Straub, Informatikrecht. Einführung in Softwareschutz, Projektverträge und Haftung, Bern 2003.

A. Szewc, Wynagrodzenia twórców i wykonawców w prawie autorskim i wynalazczym, Sopot 1999.

A. Szewc, G. Jyż, Ochrona programów komputerowych, informacji i baz danych, Bytom 2001.

J. Szyjewska-Bagińska, w: Ustawa o prawie autorskim i prawach pokrewnych. Komentarz, Warszawa 2016.

K. Święcka, J.S. Święcki, Prawo autorskie u prawa pokrewne. Komentarz. Wybór międzynarodowych aktów prawnych, Warszawa 2004.

T. Targosz, w: Prawo autorskie i prawa pokrewne, red. D. Flisak, Warszawa 2015.

T. Targosz, w: T. Targosz, K. Włodarska-Dziurzyńska, Umowy przenoszq̨ce autorskie prawa majątkowe, Warszawa 2010.

E. Traple, Umowy o eksploatację utworów w prawie polskim, Warszawa 2010.

E. Traple, Ustawowe konstrukcje w zakresie majątkowych praw autorskich i obrotu nimi w dobie kryzysu prawa autorskiego, "Rozprawy habilitacyjne” 1990, nr 179.

P. Wasilewski, „Odsprzedaż" niematerialnych kopii programów komputerowych, KPP 2014, z. 2.

K. Włodarska-Dziurzyńska, w: T. Targosz, K. Włodarska-Dziurzyńska, Umowy przenoszące autorskie prawa majątkowe, Warszawa 2010.

M. Załucki, w: Ustawa o prawie autorskim i prawach pokrewnych. Komentarz, red. P. Ślęzak, Warszawa 2017.

K. Żok, Kwalifikacja umowy o korzystanie z programu komputerowego jako usługi (Software as a Service, SaaS) - uwagi na tle prawa polskiego i wybranych zagranicznych systemów prawnych, "Zeszyty Naukowe Uniwersytetu Jagiellońskiego. Prace z Prawa Własności Intelektualnej" 2015, z. 12.9

K. Żok, Prawna i ekonomiczna analiza umowy o korzystanie z programu komputerowego jako usługi (Software as a Service, SaaS), „Zeszyty Naukowe Uniwersytetu Jagiellońskiego. Prace z Prawa Własności Intelektualnej" 2017, nr 4.

K. Żok, Środki ochrony zamawiającego program komputerowy. Odpowiedzialność twórcy za usterki utworu, Warszawa 2015.

\section{Orzecznictwo:}

Wyrok Sądu Najwyższego z dnia 4 lutego 1965 r., II CR 536/64, „Orzecznictwo Sądu Najwyższego. Izba Cywilna i Izba Pracy i Ubezpieczeń Społecznych" 1965, nr 12, poz. 215.

Wyrok Sądu Najwyższego z dnia 25 marca 2004 r., II CK 90/03, „Orzecznictwo Sądu Najwyższego. Izba Cywilna" 2005, nr 4, poz. 66.

Wyrok BGH z 11.2.2010 r., I ZR 178/08, http://juris.bundesgerichtshof.de, 2.2.2018 r.

Wyrok TSUE z 3.7.2012 r., C-128/11, w sprawie UsedSoft GmbH przeciwko Oracle International Corp., źródło: curia.europa.eu.

Wyrok Sądu Apelacyjnego w Warszawie z dnia 14 czerwca 2013 r., VI ACa 1624/12, Legalis nr 749032. Wyrok Sądu Apelacyjnego w Poznaniu z dnia 16 stycznia 2014 r., I ACa 1166/13, Legalis nr 775911. Akty normatywne:

Ustawa z dnia 4 lutego 1994 r. o prawie autorskim i prawach pokrewnych (t. jedn. Dz.U. z 2017 r., poz. 880 z późn. zm.)

Ustawa z dnia 30 maja 2014 r. o prawach konsumenta (t. jedn. Dz.U. z 2017 r., poz. 683 z późn. zm.) 


\section{Streszczenie:}

Celem tego artykułu jest przedstawienie typowych sposobów ustalania opłaty za korzystanie z programu komputerowego jako usługi i odniesienie tych uwag do uregulowania wynagrodzenia w ustawie o prawie autorskim i prawach pokrewnych. W niniejszym opracowaniu omówiono ogólne założenie ochrony twórcy jako słabszej strony umowy oraz rozważano adekwatność tego założenia w kontekście programów komputerowych, w tym także modelu oprogramowania jako usługi. Następnie przedstawiono systemy wynagradzania za korzystanie z utworu i rodzaje typowych opłat związanych z eksploatacją rozważanego dobra niematerialnego w chmurze obliczeniowej. Szczegółowej analizie poddano opłatę uzależnioną od rozmiaru rzeczywistego użycia programu komputerowego oraz opłatę uzależnioną od liczby jego użytkowników. Na tej podstawie wskazano także różnice między modelem oprogramowania jako usługi i modelem licencjonowania programów komputerowych udostępnionych na nośniku danych. W konkluzji stwierdzono, że odmienność w sposobie kształtowania powyższych opłat wynika przede wszystkim z zastosowanej technologii eksploatacji utworu.

Słowa kluczowe: oprogramowanie jako usługa, licencja, opłata, program komputerowy, wynagrodzenie.

\section{Fee in Software as a Service}

\section{Summary:}

The purpose of the article is to present typical modes of determining the fee in Software as a Service and to refer these remarks to the regulation of remuneration in Copyright and Neighbouring Rights Act. The paper discusses the general assumption, that the author as a weaker party needs a protection, and considers the adequacy of the assumption in the context of computer programs, including Software as a Service. Subsequently there are described systems of payment for using the work and kinds of typical fees connected with the exploitation of an intangible good in the cloud. The fee depending on the size of the real use of the computer programs and the fee depending on the number of users were subjected to a scrutiny. On this basis the differences between Software as a Service and licensing computer programs delivered on data media are also indicated. In the conclusion it is stated, that the divergence in the mode of shaping the aforementioned fees results mainly from the technology applied to the exploitation of the work.

Keyword: Software as a Service, license, fee, computer program, remuneration. 